IRA-International Journal of Education \& Multidisciplinary Studies ISSN 2455-2526; Vol.05, Issue 01 (2016)

Pg. no. 39-49

Institute of Research Advances

http://research-advances.org/index.php/IJEMS

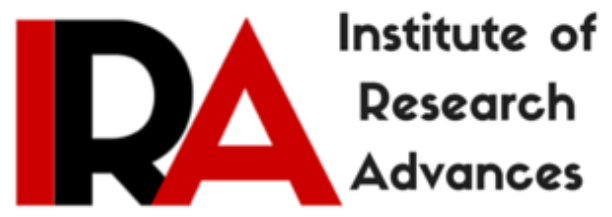

\title{
The Student Migration for Professional Courses in Mysuru City-A Sociological Study
}

\author{
${ }^{1}$ Sr. Prafula \\ Research Scholar \\ DOS in Sociology \\ University of Mysore, Mysore, India. \\ ${ }^{2}$ Dr. Rekha Jadhav \\ Research Guide \\ Associate Professor, Maharajas College \\ University of Mysore, Mysore, India.
}

Type of Review: Peer Reviewed.

DOI: http://dx.doi.org/10.21013/jems.v5.n1.p5

\section{How to cite this paper:}

Prafula, S., \& Jadhav, R. (2016). The Student Migration for Professional Courses in Mysuru City-A Sociological Study. IRA International Journal of Education and Multidisciplinary Studies (ISSN 2455-2526), 5(1), 39-49.

doi:http://dx.doi.org/10.21013/jems.v5.n1.p5

(C) Institute of Research Advances

(c)) EY-NC

This work is licensed under a Creative Commons Attribution-Non Commercial 4.0 International License subject to proper citation to the publication source of the work.

Disclaimer: The scholarly papers as reviewed and published by the Institute of Research Advances (IRA) are the views and opinions of their respective authors and are not the views or opinions of the IRA. The IRA disclaims of any harm or loss caused due to the published content to any party. 


\section{ABSTRACT}

Higher education is an asset for the society which is part of productivity and competitiveness of the Economic development. Education is the long term investment in the human capital. It is viewed as a tool for the promotion of economic growth, cultural development, social cohesion, equality and justice. Education is considered not only as an instrument of social change but also as a contributor to the individual's economic betterment for their lifetime. (Satvinderpal Kaur;2014)

Migration or movement of individual from one region to another is for various purposes. Education for migration is again a movement of a student to seek education at different places. Migration for the sake of education is a common phenomenon and thus students are migrating from one district to another, from one state to another and from country to another to opt better academic and career development. Karnataka is a hub of educational Institutions. It has renowned and reputed Professional Colleges in India. Mysuru is a city of palaces which is a very conducive environment for student migrant who come from different parts of India. This is a safe city for the student migrant. Such Students are a income generating factor for various professional Institutions in Karnataka

The main objectives of the study here is:-To study the social and Institutional support to the migrant students, Secondly to understand the psycho-socio-cultural adjustment of the migrant student in the College, Hostels, PG's and at their residing places. Thirdly to know the impact of absence of family environment among the students and their health conditions.

This study evaluates the Student migration for professional Courses in Mysuru city. This study is carried out among 120 undergraduate students from professional courses (Engineering and Medical courses). The results show that the students chose Mysuru for higher education as this city is very conducive environment for students and it is a safe place for them. Most of them are dependent on College for Campus placement. Most of the students get accustomed to the locality and the Institute and most of them feel they were healthy.

Key words: student migration, professional course, Mysuru

\section{Introduction}

Migration is a global phenomenon and a new trend among the people of all ages. People are moving freely in search of new opportunities to different places. Migration brings changes and development of places. Migration has become much easier due to mass communication and media. People move to different places keeping their own traditions and customs of their own. The new computerized age has helped the migrant to keep in touch with the family and the friends. United Nations emphasize that the people around are uprooting themselves and moving in search of a better life in record numbers, and the trend is set to grow.

World is going through a new age shift. The technological advancement in transport and communication has a significant impact on people's inclination and ability to move. More people are moving now than before due to technological advancement. People move to different places to get what is best to achieve, and something different than others. They also take risk to move to different places because they have witnessed the growth in their neighbours, as they want to be one among them. Now a days the reason for migration is not only limited to labour forces, knowledge and education and but also it has been one of the factors for the migration process. (Song Youn Jung).

Knowledge is the key to development and lack of it is a major constraint to social and economic progress. Education brings changes in the lives of people. Higher education sector plays an important role in 
facilitating the production and distribution of knowledge. India posses a highly developed higher education system which offers facility of education and training in almost all aspects of human creative and intellectual endeavors be it traditional or professional courses. In India Medical and engineering are the most preferred among the various professional courses.

India's higher education system is the third largest in the world, next to the United States and China. Indian higher system has expanded at a fast pace by adding nearly 20000 Colleges and more than 8 million students in a decade from 2000-01 to 2010-11. As of 2011, India has 42 central Universities, 275 State Universities, 130 deemed Universities, 90 Private universities, 5 Institutions established and functioning under the State Act and 33 Institutes of National Importance.

Student mobility is a movement of students to different places for higher education. Globalization has been a key driving force that has an impact that spurred student mobility. Learning opportunities around the world has also opened the gate way for the students to reach their heights in educational and cultural horizons. Professional courses nowadays are the first choice for the job seeking aspirant because they offer great opportunities and possibilities in the market place. Students stay in their respective Institutions for more than 3 to 4 years for under graduation courses. Students move to different colleges for professional courses based on their CET ranking. So the students are moving from district to district and from state to state for higher education.

\section{The main objectives of the study}

- To study the social and Institutional support to the migrant students.

- To analyze the psycho-socio-cultural adjustment of the migrant students in College premises and at their residence.

- To know the impact of absence of family environment among the students and their health conditions.

\section{Methodology of the study}

Details regarding the Student Migration for Education in Professional Courses to Mysuru city -A sociological Study was based on the information collected through questionnaire. Primary data was collected from the respondents with the help of questionnaire. Few students from medical and engineering students were interviewed by the researcher and she made an overall observation of the students in the campus and in the hostel. The secondary data was collected from the magazines and internet related to student migration.

\section{Review of Literature}

Studies show that the student migration deals with various factors such as social, financial, educational and cultural .Students migrate to different places for higher education and they are put up with difficulties such as food and accommodation problem, adjustment with culture and the environment, psychological and emotional problems, discrimination, assimilation and language etc.

Zakariya Ayed Al-Habashneh (1991) conducted a study on Jordanian student in Indian Universities, studied their backgrounds, the problem that they faced and the transformation due to the education that brought forth in their life after they returned back to the Jordanian city. 400 samples were taken at random from 4000 Jordanian student studying in Indian Universities from 1989-90. The result showed that the socio-economic and cultural backgrounds have changed and their values and perspective of the world view have transformed them, being educated by the Indian universities. They have adjusted to Indian society and they cultivated some of the values of democratic, secular, modernizing and progressing country like India. 
Kyung Wonseon (1996) examined the interstate migration of college students to the state of New York. The study found that the migration has influenced the college admission policy, student body, student body composition and the labour of a state (Abbot and Schmud). The study also investigated that the tuition fee which is different from resident and non-residents, reduced the college choices of student migration. The study also examined that the student migrant work in the state where they obtained their higher education, and they become an educated labour force for the state.The study provided a better understanding of the interstate migration of students. The study analyzed basing on 1986 New York migration data, provided the evidence that student migrant's home characteristics influenced student migration.

Mahmood Talat \& Schömann Klaus (2003) was based on the Migration Decision of IT-Graduates by using a Two-Level Nested Logit Model. The researcher analyzed the impact of choice its specific characteristics (attributes) in a model of choice between different country locations. He found that the individual IT-Graduates are assumed to choose a single type of move, stay home or go-abroad, and simultaneously choosing a country of their choice. The sample size was 1,500 IT-Graduates from Pakistan and the results showed that a high migration propensity for foreign destinations. The results shows that the university students enquired about their expectations for the future, relating to possible migration decisions during this first stage of research. The students were taken information technology and electrical engineering in their final academic year of a master's and bachelor's programme and, hence, possessed to the highest academic education equivalent to that of academically trained German engineers.

Bahiru Teshome Wondwosen (2006) investigated a study on Student's migration. Like any other migration involves a continuous process of interaction through which members of different social and cultural background come in contact with one another and together with the new socio-cultural situations. The study examined that in the University of Pune, the students of different social, ethnic, cultural and linguistic backgrounds from different continents and countries come in search for academic knowledge. This study is about African students in Pune city, deals with their perceptions towards the host population and the inter and intra racial relationships and cross-cultural interactions. In this study both qualitative and quantitative data have been used. In order to gather information about the African students' community life and their national and religious association, a quasi-participant observation technique was employed. It is found out that due to many pull and push factors African students move to India. The push factors include: the shortage of higher academic institutions in Africa, and to a certain extent political instability.The pull factors include: the relatively affordable educational expenses in India, and the fast and less complicated University and College admission procedures.

Verbik Line (2007) invested a study on international student mobility, the changing the global higher education landscape, with an increasing number of students going abroad for tertiary studies. The study has identified the competitive measures that the nations are taking in order to increase their share of the global student market. The research identified several important trends and emerging patterns among international students. The study showed that, the US dominates the international student market, because of its 'brand' visibility and established international reputation. The study revealed that Germany and France, attracted solid numbers from a variety of countries, albeit those with geographic or historical connections. Japan, Canada and New Zealand largely depend on one or two countries to source their overseas students.

Agasisti Tommaso \& Dal Bianco Antonio (2007) examined the determinants of College Student Migration in Italy. Theoretical considerations suggested that both the university characteristics and socioeconomic conditions of the geographical areas in which they are located are important. An empirical analysis has been conducted using a gravity model, in which the distance from the area of residence to the destination (university location) plays a deterrent role. The results confirmed that "frictional" role of 
distance, and the number of faculties, the resources invested in student aid, and the socio-economic conditions of the area have a positive impact on the attractiveness of a university.

\section{Age of the respondent}

\begin{tabular}{|c|c|c|c|c|c|}
\hline & & Frequency & Percent & Valid Percent & $\begin{array}{l}\text { Cumulative } \\
\text { Percent }\end{array}$ \\
\hline \multirow{10}{*}{ Valid } & 22 & 12 & 10.0 & 10.0 & 10.0 \\
\hline & 21 & 14 & 11.7 & 11.7 & 21.7 \\
\hline & 20 & 22 & 18.3 & 18.3 & 40.0 \\
\hline & 19 & 31 & 25.8 & 25.8 & 65.8 \\
\hline & 18 & 27 & 22.5 & 22.5 & 88.3 \\
\hline & 17 & 8 & 6.7 & 6.7 & 95.0 \\
\hline & 23 & 3 & 2.5 & 2.5 & 97.5 \\
\hline & 24 & 1 & .8 & .8 & 98.3 \\
\hline & 25 & 2 & 1.7 & 1.7 & 100.0 \\
\hline & Total & 120 & 100.0 & 100.0 & \\
\hline
\end{tabular}

\section{Profile of the respondent}

The average age for professional student is between 17 to 19 years for professional courses. $25.8 \%$ of them belong to the age group of 19 and only $1.7 \%$ of them belong to the age group of 25 . The age difference is based on the semester in which they are studying.

Religion
\begin{tabular}{|l|l|l|l|l|}
\hline & Frequency & Percent & Valid Percent & Cumulative Percent \\
\hline Hindu & 89 & 74.2 & 74.2 & 74.2 \\
Muslim & 5 & 4.2 & 4.2 & 78.3 \\
Christian & 23 & 19.2 & 19.2 & 97.5 \\
others & 3 & 2.5 & 2.5 & 100.0 \\
Total & 120 & 100.0 & 100.0 & \\
\hline
\end{tabular}

All the religious group want to increase the literacy level .Hinduism is the major Religion in India. The students from every religious group come to Mysuru for professional course. The table shows that majority of the students are Hindus (74.2\%) Christian (19.2\%) and Muslims (4.2\%) and others such as Jains and Buddhists (2.5\%) who come from different parts of India to Mysuru for professional course.

\section{Duration of the stay}

Mysuru is also one of the educational hub in Karnataka .People from all over the state, outside state and outside India see Mysuru as their destiny for higher education. Mysuru welcomes the students from intercity, inter-state and international students to various reputed colleges in Mysuru. 


Duration of the stay
\begin{tabular}{|l|l|l|l|l|}
\hline & Frequency & Percent & Valid Percent & $\begin{array}{l}\text { Cumulative } \\
\text { Percent }\end{array}$ \\
\hline 1 year & 23 & 19.2 & 19.2 & 19.2 \\
2 year & 21 & 17.5 & 17.5 & 36.7 \\
3 year & 17 & 14.2 & 14.2 & 50.8 \\
Valid 4 year & 13 & 10.8 & 10.8 & 61.7 \\
5 year & 21 & 17.5 & 17.5 & 79.2 \\
6 year & 24 & 20.0 & 20.0 & 99.2 \\
10 year & 1 & .8 & .8 & 100.0 \\
Total & 120 & 100.0 & 100.0 & \\
\hline
\end{tabular}

The above table shows the duration of the stay of the students in Mysuru. The students come to Mysuru for their study staying here for one year to 10 years. The first year students $(19.2 \%)$ and others $(20 \%)$ of them who are the final year students stayed here for six years $(14.2 \%)$ for 3 years $(10.8), 4$ years $(17.5 \%)$ for 5 years etc

Native place of the students

\begin{tabular}{|ll|l|l|l|l|}
\hline & Frequency & Percent & Valid Percent & $\begin{array}{l}\text { Cumulative } \\
\text { Percent }\end{array}$ \\
\hline AP & 14 & 11.7 & 11.7 & 11.7 \\
Kerala & 39 & 32.5 & 32.5 & 44.2 \\
Valid & TN & 1 & .8 & .8 & 45.0 \\
North & 45 & 37.5 & 37.5 & 82.5 \\
N-E & 21 & 17.5 & 17.5 & 100.0 \\
Total & 120 & 100.0 & 100.0 & \\
\hline
\end{tabular}

In Mysuru we find people from different states and from international countries coming for various reasons such as employment, education and transfer or marriage. Some of them have stayed permanently and got adjusted to the place and others like students who are here for two to five years are getting used to the place of their stay. Above table shows that 32.5\% have come from Kerala, $37.5 \%$ of them north, $17.5 \%$ of them from North-East, $11.7 \%$ from Andhra Pradesh, and .8\% from Tamil Nadu. This shows that the students come to Mysuru from different parts of India for higher education.

\section{Place of stay at Mysuru}

Mysuru is very safe place for students. The migrant students who come here prefer to stay in the hostel attached to the College (50\%). Parents prefer their ward to stay in the hostels which are more safe than staying outside. $10 \%$ of them have taken rented rooms or rented flats for their stay while others $15 \%$ of them have their own house and $5.8 \%$ of them stay in leased house. The study observed that as they stay longer they like to stay outside for more freedom and explore the city of Mysuru. 


\begin{tabular}{|c|c|c|c|c|c|}
\hline \multicolumn{6}{|c|}{ Place of stay } \\
\hline & & Frequency & Percent & Valid Percent & $\begin{array}{l}\text { Cumulative } \\
\text { Percent }\end{array}$ \\
\hline \multirow{7}{*}{ Valid } & hostel & 60 & 50.0 & 50.0 & 50.0 \\
\hline & PG & 11 & 9.2 & 9.2 & 59.2 \\
\hline & Rented Room & 12 & 10.0 & 10.0 & 69.2 \\
\hline & Rented Flat & 12 & 10.0 & 10.0 & 79.2 \\
\hline & own house/flat & 18 & 15.0 & 15.0 & 94.2 \\
\hline & lease house & 7 & 5.8 & 5.8 & 100.0 \\
\hline & Total & 120 & 100.0 & 100.0 & \\
\hline
\end{tabular}

\section{Social and Institutional support}

Social support is a set of perceived general or specific supportive behaviors that contribute to a person's physical and mental well-being generally as a buffer for someone under stress (Malecki \& Demaray , 2002a). Social support is the perception and actuality that one is cared for, has assistance available from other people. These supportive resources can be emotional support, financial support, informational support or companionship from family members, neighbours, etc. social support increases psychological well-being for the students and they feel more comfortable to complete their studies without any hindrance.

Government- provided social support is often referred to as public aid. Government gives financial assistance to students through scholarships and loans through various banks. Government sees that the students who want to continue their professional courses are given subsidy and financial assistance. Institutional support is what students get from the Institutions. The Institutions give academic assistance, career decision making and provides career placement.

Social and Institutional Support

\begin{tabular}{|ll|l|l|l|l|}
\hline & Frequency & Percent & Valid Percent & $\begin{array}{l}\text { Cumulative } \\
\text { Percent }\end{array}$ \\
\hline \multirow{4}{*}{ Valid don't know } & 32 & 26.7 & 26.7 & 26.7 \\
no & 12 & 10.0 & 10.0 & 36.7 \\
yes & 76 & 63.3 & 63.3 & 100.0 \\
Total & 120 & 100.0 & 100.0 & \\
\hline
\end{tabular}

The above table reveals that $63.3 \%$ of the students feel that they get sufficient social and Institutional support and only $10 \%$ of them felt that they never received any social and Institutional support. About $26.7 \%$ of the students were ignorant about the social and Institutional support.

The support that they received were scholarships, celebration of festivals, linguistic association, concessions, extra holidays, bank loan, travel concessions, care and concern, health facility,Wi-Fi facility, well furnished rooms, conducive environment for study, spiritual nourishment and a home away from home. These were rated on the basis of very satisfactory, satisfactory, average, unsatisfactory and very unsatisfactory. The student were unhappy about the scholarships, $25 \%$ of them were very unsatisfactory and $15 \%$ of the unsatisfactory. On an average $27.5 \%$ the students has not applied or just ignored about the scholarship and few students $20.8 \%$ of them satisfactory and about $11.7 \%$ and very satisfactory $(11.7 \%)$.The students were quite satisfactory $48.3 \%$ of them about the celebrations. $36.7 \%$ of the students 
were satisfied with the linguistic association in the college and only $1.7 \%$ were unhappy about it. On an average $46.7 \%$ were just neutral about the concessions that they received in the college. Those students who wanted to go to their native place had taken extra holidays and only $27.5 \%$ of them felt satisfied and $12.5 \%$ felt very unsatisfied about the arrangements made by the college regarding extra holidays. $23.3 \%$ of them were satisfied with travel concessions and the $41.75 \%$ of them on an average were satisfied with the loan facility but most of their fees and other expenses were met by their parents. The students who stayed at the hostel and outside felt that they were satisfied $(43.3 \%)$ with the care and concern they received from the institution and the locality. $20.8 \%$ were very happy with the care and concern regarding their stay and everything that they received from the Institute. Students were very unhappy with Wi-Fi facility $(22.5 \%)$, satisfied (37.5\%) with the room facility, conducive environment for study (45\%) and the spiritual nourishment on an average (33.3\%) and felt that Mysuru is a place, a home away from home for the student $(32.5 \%)$.On the whole the students were happy with everything and only few of them were unsatisfied with the support system of the Institute and the government.

\section{Psycho-socio-cultural adjustment}

Socio-cultural adjustment refers to ability to "fit in" to the culture of the society. They learn the culture by living and observing and slowly becoming a part of the society. It depends upon how long you stay there in the place. The longer you stay the more you get adjusted to the place, to the people, and the language. Keeping distance with the local people shows indifferent attitude towards the place.

According to Berry, Kim \& Boski (1988) there are different strategies of adaptation process that lead to varieties of adaptation as a state. The most common form of these strategies is adjustment, which refers to behavioural changes that reduces the conflict with the environment and the behavior.

Tests of Between-Subjects Effects

Dependent Variable: gender

\begin{tabular}{|l|l|l|l|l|l|}
\hline Source & $\begin{array}{l}\text { Type III Sum } \\
\text { of Squares }\end{array}$ & df & Mean Square & F & Sig. \\
\hline Corrected & $4.360^{\mathrm{a}}$ & 4 & 1.090 & 4.889 & .001 \\
Model & 182.611 & 1 & 182.611 & 819.054 & .000 \\
Intercept & 4.360 & 4 & 1.090 & 4.889 & .001 \\
Adjust very well & 25.640 & 115 & .223 & & \\
Error & 300.000 & 120 & & & \\
Total & 30.000 & 119 & & & \\
Corrected Total &
\end{tabular}

a. R Squared $=.145$ (Adjusted R Squared $=.116)$

The students on an average are socially, psychologically and culturally adjusted to the Institutions and the locality. the above table shows the mean score 1.090 and the student have adjusted to the place very well in spite of them staying away from parent for the first time (47.2\%) and they also expressed that friends and relatives $(25.8 \%)$ have supported them to adjust to the place.

\section{Impact of absence of family environment}

Family environment is very suitable for physical, emotional and spiritual growth among the youth. Healthy family environment is very essential for all- round development of personality .It encourages good behavior and keep them away from unwanted behavior. Every kind of migration has a considerable impact on both the individual and the family. The students who are away from the family lack the special care and attention that they receive at home. The impact is very profound on the social and cultural aspects of life. 
The study found that most of the students (43\%) keep in touch with the family and friends every day, no matter where they are, only $10 \%$ of the students revealed that they never contacted their friends or relatives. Most of them uses the modern gadgets such as social net working and whatsapp to chat with friends and relatives. Students slowly start to develop social relationship and contacts with their peer group and are more influenced by them than their parents. They seek their help to solve their personal problems and obey them than their parents.

Absence of the parents has both negative and positive aspects, The student who stay in Mysuru has adopted western life style (45\%), have become more independent $(51.7 \%)$ become more competitive (44.2\%) and they have cultivated superficial behavior (39.2), have become more self-centered (30.8) etc.

\section{Health conditions.}

Health General
\begin{tabular}{|c|l|l|l|l|}
\hline \multicolumn{1}{|c|}{} & Frequency & Percent & Valid Percent & $\begin{array}{l}\text { Cumulative } \\
\text { Percent }\end{array}$ \\
\hline very poor & 2 & 1.7 & 1.7 & 1.7 \\
Valid gair & 18 & 15.0 & 15.0 & 16.7 \\
good & 78 & 65.0 & 65.0 & 81.7 \\
very good & 22 & 18.3 & 18.3 & 100.0 \\
Total & 120 & 100.0 & 100.0 & \\
\hline
\end{tabular}

Being healthy is very important for all round development. The students are generally healthy and $65 \%$ of them feel that their health status is good and $1.7 \%$ of them feel that their health is very poor. The medical students take care of their health since they themselves are aware of the consequences of being ill. Some of the students are very delicate and they are unable to cope up with the environment, food and fall ill soon. The reasons for falling ill is mainly because they are not able to adjust to the type of food. The students come from south, north and west and north-east so the taste differ and they take time to adjust with south Indian food. They fall ill sometimes due to changes in climatic conditions and pollution and eating of junk food from outside. A disciplined life may protect them in taking care if their health. Health Insurance policy, regular check up will boost their health. The students are too busy with their studies hardly they get time to waste and to time have recreation.

The students felt that health facility was very unsatisfactory for few of them (5.8\%) and others felt that they are satisfied $(39.2 \%)$ and $20.8 \%$ very satisfied with the health facility provided by the institution.

\section{Findings and suggestions}

Migration is a positive process that brings people of different cultures and gives them new avenues to learn new things and broaden their horizons. Both the students and the people in the locality get affected by the migration.

- The study found that out of 120 students 60 are male and 60 are female ( 60 students from Engineering Course and 60 from Medical course)

- There are no Religious differences when it comes for higher education; parents at their own risk send their wards for professional course to different parts of the country for a promising future. The study found that the students belongs to Hindus (74.2\%) Christians (19.2\%) and Muslims (4.2\%) and others such as Jains and Buddhists (2.5\%) respectively.

- Students migrate for professional courses in various parts of India and abroad. It was found that majority of the students who came to Mysuru for professional course are from $32.5 \%$ have come 
from Kerala, $37.5 \%$ of them north, $17.5 \%$ of them from North-East, $11.7 \%$ from Andhra Pradesh, and $.8 \%$ from Tamil Nadu which reveals that for higher education students go to any parts of India based on their choice and the seat availability.

- The students who enroll for professional course can start their own business or clinic after the completion of the study. The study observed that few students are very much interested in making money than their mission.

- The students who stayed more years are more comfortable than the students who are just joined for the course, feel more home sick and gradually they get used to the new environment.

- The geographical area i.e. the distance from the College and home towns allows them to visit their native place, during the semester-end and on special occasions.

- The study explored that about $42.9 \%$ of the students were happy with the social, emotional and spiritual support.

- Most of the students are physically, socially and psychologically healthy

- The culture of the society also helps them to develop their personality holistically.

- Students slowly start to develop social relationship and contacts with their peer group and are more influenced by them than their parents. They seek their help to solve their personal problem and obey them than their parents.

\section{Conclusion}

Migration of individual from one region to another is for various purposes .Education for migration is movement of student for education to different places which is a common phenomenon for better academic and career development. Karnataka is one of the pioneer states in the country to introduce reforms in higher education. Karnataka has already made a beginning in the field of higher education. Considerable progress has been made in Karnataka with the establishment of more than twenty universities and a large number of undergraduate colleges. Mysuru city is one of the prime education hub for undergraduate education .In almost all the city schools, College and Universities we find migrant students in big number.

Every kind of migration has a considerable impact on both the individual and the family. The Impact is profound on the social and cultural aspects of life than on the economic and political.

\section{Reference}

1. S.Irudaya Rajan and Neha Wadhawan (2013) 'Future Diasporas? International student Migration from India to the UK

2. JA, H., DW, M., \& JR, B. (2007). Migration of doctors for undergraduate medical education. Educational Commission for Foreign Medical Graduates, Philadelphia, PA 19104-2685, USA. jhallock@ecfmg.org, 98-105.

3. Line, V. (2007). 'International Student mobility ,patterns and Trends. the observatory on borderless higher education .

4. chttp://siteresources.worldbank.org/EDUCATION/Resources/278200-1121703274255/14392641193249163062/India_CountrySummary.pdf

5. Spring, J. 2009, Globalization of Education: An Introduction, Queens College \& Graduate Centre, City University of New York

6. Tommaso, A., \& Dal Bianco, A. (2007, December 5). Retrieved from Social Science Electronic Publishing: http://ssrn.com/abstract=1063481 
7. Wei, S. Student Migration Between China and Europe Politics, Policy and Prospects. Loughborough University \& Sciences Po Paris.

8. et.al, B. A. Forecasting international student mobility a UK perspective. British Council.

9. Wonseon, K. (1996). In-Migration of collge studnets to the state of New York. The Journal of higher education , 349-358.

10. Zakaria Ayed, A.-H. (1991). The Jordanian students in Indian universities-A sociological study of their backgrounds, problems, aspirations and perceptions as future agents of social change and modernization in Jordan. vidanidhi digital library, University of Myosre .

11. Wondwosen, B. T. (2006). social science reserach network. Retrieved from http://ssrn.com/abstract=1080814

12. Wonseon, K. (1996). In-Migration of collge studnets to the state of New York. The Journal of higher education , 349-358.

13. http://www.unesco.org/iiep/PDF/pubs/2008/Globalization_HE.pdf

14. http://psycnet.apa.org/psycinfo/2001-05113-000

15. http://go.galegroup.com/ps/anonymous?id=GALE\%7CA110797311\&sid=googleScholar\&v=2.1 \&it=r\&linkaccess=fulltext $\&$ issn $=02796015 \& \mathrm{p}=\mathrm{AONE} \& \mathrm{sw}=\mathrm{w} \&$ authCount $=1 \&$ is AnonymousEnt ry $=$ true 